\title{
EFEKTIVITAS BERBAGAI KONSENTRASI EKSTRAK DAUN CENGKEH (Syzygium aromaticum, L.) SEBAGAI REPELLENT TERHADAP DAYA HINGGAP NYAMUK Aedes aegypti
}

\author{
Aji Pandu Zulaikha ${ }^{1)}$, Arif Widyanto ${ }^{2)}$, Teguh Widiyanto ${ }^{3)}$ \\ Poltekkes Kemenkes Semarang, Poltekkes Kemenkes Semarang, Poltekkes Kemenkes Semarang
}

\begin{abstract}
Abstrak
Demam Berdarah Dengue (DBD) adalah penyakit yang disebabkan oleh virus dengue yang ditularkan melalui gigitan nyamuk Aedes aegypti. Pengendalian kimiawi sebagai salah satu pengendalian yang aman terhadap kesehatan dan ramah lingkungan adalah dengan menggunakan repellent alami. Daun cengkeh merupakan bagian tanaman yang mengandung eugenol, flavonoid, saponin dan tanin yang dapat bermanfaat sebagai repellent untuk mengendalikan nyamuk Aedes aegypti. Tujuan penelitian yaitu dapat diketahuinya efektivitas berbagai konsentrasi ekstrak daun cengkeh (Syzygium aromaticum, L.) sebagai repellent terhadap nyamuk Aedes aegypti. Jenis penelitian ini adalah eksperimen kuasi/semu dengan desain penelitian posttest only control group. Analisis statistik yang digunakan One-way Anova dengan uji lanjut LSD (Least Significant Difference). Hasil penelitian menunjukkan bahwa konsentrasi $10 \%$ mempunyai daya hinggap $11,2 \%$, konsentrasi $20 \%$ mempunyai daya hinggap $11,2 \%$, konsentrasi $40 \%$ mempunyai daya hinggap 7,2\%, konsentrasi $80 \%$ mempunyai daya hinggap 5,2\%. Hasil analisis One-way Anova terbukti signifikan dengan nilai $\mathrm{p}=0,000<\alpha(0,05)$, sehingga ada perbedaan nyamuk Aedes aegypti yang hinggap pada tangan probandus dengan berbagai konsentrasi ekstrak daun cengkeh. Kesimpulan penelitian adalah konsentrasi $80 \%$ ekstrak daun cengkeh efektif sebagai repellent terhadap nyamuk Aedes aegypti. Disarankan agar peneliti lain melakukan penelitian menggunakan ekstrak daun cengkeh dengan metode ekstraksi yang berbeda atau penelitian daya proteksi atau menggunakan jenis tanaman lain.
\end{abstract}

Kata kunci : Repellent; Aedes aegypti; Ekstrak Daun Cengkeh

\begin{abstract}
Dengue Hemorrhagic Fever (DHF) is a disease caused by dengue that transmitted through the bite of Aedes aegypti mosquito. Chemical control as one of the safest control on health and environment is to use natural repellent. Clove leaf is a part of plant that contains eugenol, flavonoid, saponin and tannins which can be used as repellent to control Aedes aegypti mosquito. The purpose of this research is to know the effectiveness of clove leaf extract concentrate (Syzygium aromaticum, L.) as Aedes aegypti mosquito repellent. The type of this research is quasi experiment with posttest only control group research design. Statistical analysis used One-way Anova with LSD (Least Significant Difference) advanced test. The result showed that $10 \%$ concentrate had 11,2\% power perching, 20\% had 11,2\% power perching, $40 \%$ concentrate had 7,2\% power perching, $80 \%$ concentrate had 5,2\% power perching. The result of One-way Anova proved significantly with $p=0,000<\alpha(0,05)$ value, so there is a difference of Aedes aegypti mosquito which alighted on the probandus hand with clove leaf extract concentrate. The conclusion of the research is clove leaf extract has not effective as repellent against Aedes aegypti. It is recommended others researchers conduct research using clove leaf extract with different methods of extraction or research of power protection or use another plant species.
\end{abstract}

Keywords : Repellent, Aedes aegypti; Clove Leaf Extract 


\section{Pendahuluan}

Demam Berdarah Dengue (DBD) atau Dengue Hemorhagic Fever (DHF) merupakan salah satu penyakit infeksi yang banyak tersebar di Indonesia dan menimbulkan banyak korban jiwa bahkan insidennya cenderung meningkat dari tahun ke tahun. Di Indonesia penyakit DBD pertama kali dilaporkan di Jakarta dan Surabaya pada tahun 1972. Sejak itu, penyakit DBD menyebar ke berbagai daerah, sehingga sampai tahun 1980 seluruh propinsi di Indonesia telah terjangkit. Penyebab meningkatnya jumlah kasus dan semakin menyebar luasnya penyakit ini antara lain karena meningkatnya transportasi (mobilitas) penduduk dari satu daerah ke daerah lain utamanya pada lingkungan perkotaan yang padat (Hadinotonegoro \& Satari, 2002, dalam Farida 2017).

Demam Berdarah Dengue adalah penyakit yang disebabkan oleh virus dengue yang ditularkan melalui gigitan nyamuk Aedes aegypti. Penularan penyakti DBD pada dasarnya terjadi karena adanya penderita maupun pembawa virus dengue, nyamuk Aedes aegypti sebagai vektor dan masyarakat sebagai sasarannya (Sukana, 1993).

Permenkes RI Nomor 50 Tahun 2017 penyakit yang ditularkan melalui vektor masih menjadi penyakit endemis yang dapat menimbulkan wabah atau kejadian luar biasa serta memberikan dampak kerugian ekonomi masyarakat sehingga perlu dilakukan upaya pengendalian atas penyebaran vektor. Pengendalian vektor merupakan kegiatan atau tindakan yang ditujukan untuk menurunkan populasi vektor serendah mungkin sehingga keberadaannya tidak lagi beresiko untuk terjadinya penularan penyakit sehingga penyakit akibat vektor dapat dicegah. Di Indonesia, penyakit-penyakit yang ditularkan melalui larva nyamuk merupakan penyakit endemis pada daerah tertentu, seperti Demam Berdarah Dengue (DBD) yang ditularkan melalui gigitan nyamuk Aedes aegypti.

Upaya penanggulangan Penyakit Demam Berdarah Dengue dapat dilakukan dengan pengendalian vektor nyamuk dan pencegahan yaitu mengurangi frekuensi kontak atau memutus kontak antara manusia dengan vektor nyamuk. Menurut salah satu penelitian yang menyatakan bahwa cara mengurangi kontak dengan nyamuk yang paling baik adalah dengan pemakaian anti-nyamuk dan memakai pakaian tertutup yang dapat melindungi dari nyamuk. Di dunia termasuk Indonesia telah beredar losion anti-nyamuk yang mengandung DEET (Diethyl toluamide) $10-15 \%$, senyawa ini termasuk kimia sintesis yang dapat digunakan untuk menghindari nyamuk. Namun, penggunaan yang terlalu sering dan dosis yang berlebihan akan menimbulkan dampak bagi kesehatan manusia. Beberapa penelitian melaporkan bahwa pemakaian DEET menyebabkan keracunan dari yang ringan seperti ultikaria pada kulit, sampai yang paling parah seperti ensafalopati (Heni, hal 86-87, 2016).

Penggunaan bahan alami sebagai salah satu pengendalian yang aman terhadap kesehatan dan ramah lingkungan menjadi pilihan bagi masyarakat. Repellent alamiah adalah dengan memanfaatkan tanaman sebagai biopestisida. Daya tolak terhadap nyamuk pada umumnya diperoleh dari bau menyengat yang berasal dari senyawa minyak astiri (Heni, hal 87, 2016).

Repellent nyamuk ini dapat diambil dari suatu tanaman yang memiliki kandungan minyak atsiri. Minyak atsiri dihasilkan oleh suatu kelenjar khusus dari tanaman yang mempunyai bau yang khas dan khasiat yang tinggi sehingga dapat bersifat sebagai repellent nyamuk (Manaf, 2009, hlm. 31-37). Jenis tanaman yang sering dimanfaatkan untuk repellent antara lain serai wangi, sirih, cengkeh, zodia, lavender.

Cengkeh merupakan tanaman rempah asli Maluku Utara/Kepulauan Maluku dan telah di perdagangkan serta dibudidayakan secara turun-temurun dalam bentuk perkebunan rakyat. Pemisahan kandungan kimia dari daun cengkeh menunjukkan bahwa daun cengkeh mengandung saponin, alkaloid, glikosida flavonoid dan tannin (Talahatu, 2015, hlm. 149-159).

Hasan Boesri dkk (2015) melakukan penelitian tentang uji repelen (daya tolak) beberapa ekstrak tumbuhan terhadap gigitan nyamuk Aedes aegypti vektor demam berdarah dengue menunjukkan ekstrak daun cengkeh pada konsentrasi $100 \%$ mampu menolak selama 4 jam sebanyak $81,7 \%$. Berdasarkan hal tersebut peneliti mencoba melakukan penelitian dengan judul : "Efektivitas Berbagai Konsentrasi Ekstrak Daun Cengkeh (Syzygium aromaticum, L.) sebagai Repellent Terhadap Daya Hinggap Nyamuk Aedes aegypti”.

\section{Bahan dan Metode}

Jenis penelitian ini adalah penelitian eksperimen kuasi/semu dengan desain penelitian posttest only control group. Sampel dalam penelitian ini adalah nyamuk Aedes aegypti

\footnotetext{
1) Email : zajipandu@ gmail.com

2)Email : arifwidyanto74@yahoo.com

${ }^{3)}$ Email : widiyantoteguh@yahoo.co.id
} 
betina hasil rearing di Loka Litbang P2B2 Pangandaran. Jumlah nyamuk yang digunakan sebanyak 25 ekor untuk tiap kurungan. Pada penelitian ini digunakan 4 buah kurungan untuk pengujian tiap konsentrasi. Jumlah total nyamuk Aedes aegypti yang digunakan 25 ekor dikali 4 sama dengan 100 ekor nyamuk Aedes aegypti. Pengulangan yang digunakan dalam penelitian ini adalah 10 kali. Metode penelitiannya yaitu, menyiapkan alat dan bahan yang akan digunakan. Memasukkan nyamuk Aedes aegypti ke dalam kurungan nyamuk masing - masing 25 ekor. Setiap perlakuan diberi konsentrasi $10 \%$, $20 \%$, 40\% dan $80 \%$ pada masing - masing tangan kiri probandus. Tangan kanan probandus diberi hand body lotion untuk kontrol. Memasukan tangan kanan probandus (kontrol) ke dalam kurungan nyamuk dan paparkan selama 10 menit setiap jam dalam rentang waktu 6 jam. Memasukan tangan kiri probandus ke dalam kurungan nyamuk dan paparkan selama 10 menit setiap jam dalam rentang waktu 6 jam. Setiap perlakuan dihitung nyamuk yang hinggap pada tangan probandus, untuk mengetahui efek repellent ekstrak daun cengkeh.

\section{Hasil dan Pembahasan}

a. Suhu udara

Hasil pengukuran suhu udara pada tempat penelitian (Laboratorium Loka Litbang P2B2 Pangandaran) adalah sebagai berikut :

Tabel 4.1 Hasil Pengukuran Suhu Udara Pada Saat Awal Waktu Kontak dan Pengamatan 6 Jam Setelah Pengujian Di Tempat Penelitian

\begin{tabular}{cccc}
\hline \multirow{2}{*}{$\begin{array}{c}\text { Jenis } \\
\text { Repellent }\end{array}$} & Konsentrasi & $\begin{array}{c}\text { Suhu } \\
\text { Awal } \\
\left({ }^{\circ} \mathbf{C}\right)\end{array}$ & $\begin{array}{c}\text { Suhu } \\
\text { Setelah } \\
6 \text { Jam } \\
\left({ }^{\circ} \mathbf{C}\right)\end{array}$ \\
\hline \multirow{2}{*}{$\begin{array}{c}\text { Ekstrak } \\
\text { Daun } \\
\text { Cengkeh }\end{array}$} & $10 \%$ & 26,5 & 27 \\
\cline { 2 - 4 } & $20 \%$ & 26,5 & 27 \\
\cline { 2 - 4 } & $40 \%$ & 26,5 & 27 \\
\hline \multicolumn{2}{c}{ Rata-rata } & 26,5 & 27 \\
\hline
\end{tabular}

Rata-rata suhu optimum untuk pertumbuhan nyamuk adalah $25-27^{\circ} \mathrm{C}$ dan pertumbuhan nyamuk akan berhenti sama sekali bila suhu kurang dari $10^{\circ} \mathrm{C}$ atau lebih dari $40^{\circ} \mathrm{C}$ (Yotopranoto et al, 1998, dalam Yudhastuti \& Anny, 2005).

Kondisi suhu udara di ruang penelitian sebagaimana terdapat pada tabel 4.1 yaitu rata-rata suhu awal sebelum pengujian $26,5^{\circ} \mathrm{C}$ dan rata-rata setelah 6 jam pengujian $27^{\circ} \mathrm{C}$. Pengukuran suhu udara bertujuan untuk mengetahui suhu ruang saat uji repellent. Suhu udara diukur dengan menggunakan thermometer yang diletakkan di dinding ruangan. Ruangan tersebut terdapat AC sehingga dapat mengontrol suhu udara agar tetap stabil pada suhu $26-27^{\circ} \mathrm{C}$. Suhu stabil yang dihasilkan oleh AC menyebabkan nyamuk dapat tetap hidup dengan tidak dehidrasi.

\section{b. Kelembaban udara}

Hasil pengukuran kelembaban udara pada tempat penelitian (Laboratorium Loka Litbang P2B2 Pangandaran) adalah sebagai berikut :

Tabel 4.2 Hasil Pengukuran Kelembaban Udara Pada Saat Awal Waktu Kontak dan Pengamatan 6 Jam Setelah Pengujian Di Tempat Penelitian

\begin{tabular}{|c|c|}
\hline $\begin{array}{c}\text { Jenis } \\
\text { Repellent }\end{array}$ & $\begin{array}{l}\text { Kelembab } \\
\text { an Setelah } \\
6 \text { Jam (\%) }\end{array}$ \\
\hline \multirow{4}{*}{$\begin{array}{c}\text { Ekstrak } \\
\text { Daun } \\
\text { Cengkeh }\end{array}$} & $10 \%$ \\
\hline & $20 \%$ \\
\hline & $40 \%$ \\
\hline & $80 \%$ \\
\hline Rata-rata & $\begin{array}{ll}78 & 77\end{array}$ \\
\hline \multicolumn{2}{|c|}{$\begin{array}{l}\text { Kelembaban yang baik untuk } \\
\text { perkembangan nyamuk dan serangga pada } \\
\text { umumnya adalah sekitar } 70 \%-89 \% \text {. Pada } \\
\text { kelembaban kurang dari } 60 \% \text {, umur } \\
\text { nyamuk akan menjadi pendek karena tidak } \\
\text { cukup untuk siklus pertumbuhan parasit } \\
\text { dalam tubuh (Jumar, 2000, dalam } \\
\text { Manurung dkk, 2013). }\end{array}$} \\
\hline \multicolumn{2}{|c|}{$\begin{array}{l}4.2 \text { yaitu rata-rata kelembaban udara ruang } \\
\text { sebelum pengujian yaitu } 78 \% \text { dan rata-rata } \\
\text { setelah } 6 \text { jam pengujian } 77 \% \text {. Dalam ruang } \\
\text { penelitian dengan kelembaban udara } 77 \% \\
\text { sangat mendukung bagi kelangsungan } \\
\text { hidup nyamuk uji yang terdapat pada } \\
\text { kurungan nyamuk. }\end{array}$} \\
\hline \multicolumn{2}{|c|}{ Jumlah nyamuk Aedes aegypti yang } \\
\hline \multicolumn{2}{|c|}{$\begin{array}{l}\text { probandus sebanyak } 3 \text { gram, selanjutnya } \\
\text { tangan dimasukkan pada kurungan. }\end{array}$} \\
\hline \multicolumn{2}{|c|}{$\begin{array}{l}\text { Nyamuk yang hinggap di tangan probandus } \\
\text { diamati dan dihitung jumlahnya. Jumlah }\end{array}$} \\
\hline
\end{tabular}


tangan probandus yang diolesi repellent ekstrak daun cengkeh dengan konsentrasi $10 \%, 20 \%, 40 \%$ dan $80 \%$ dengan replikasi sebanyak 10 kali dapat dilihat pada tabel berikut :

Tabel 4.3 Jumlah Nyamuk Aedes Aegypti Yang Hinggap Pada Tangan Probandus Setelah Diolesi Ekstrak Daun Cengkeh Dengan Lama Paparan 6 Jam.

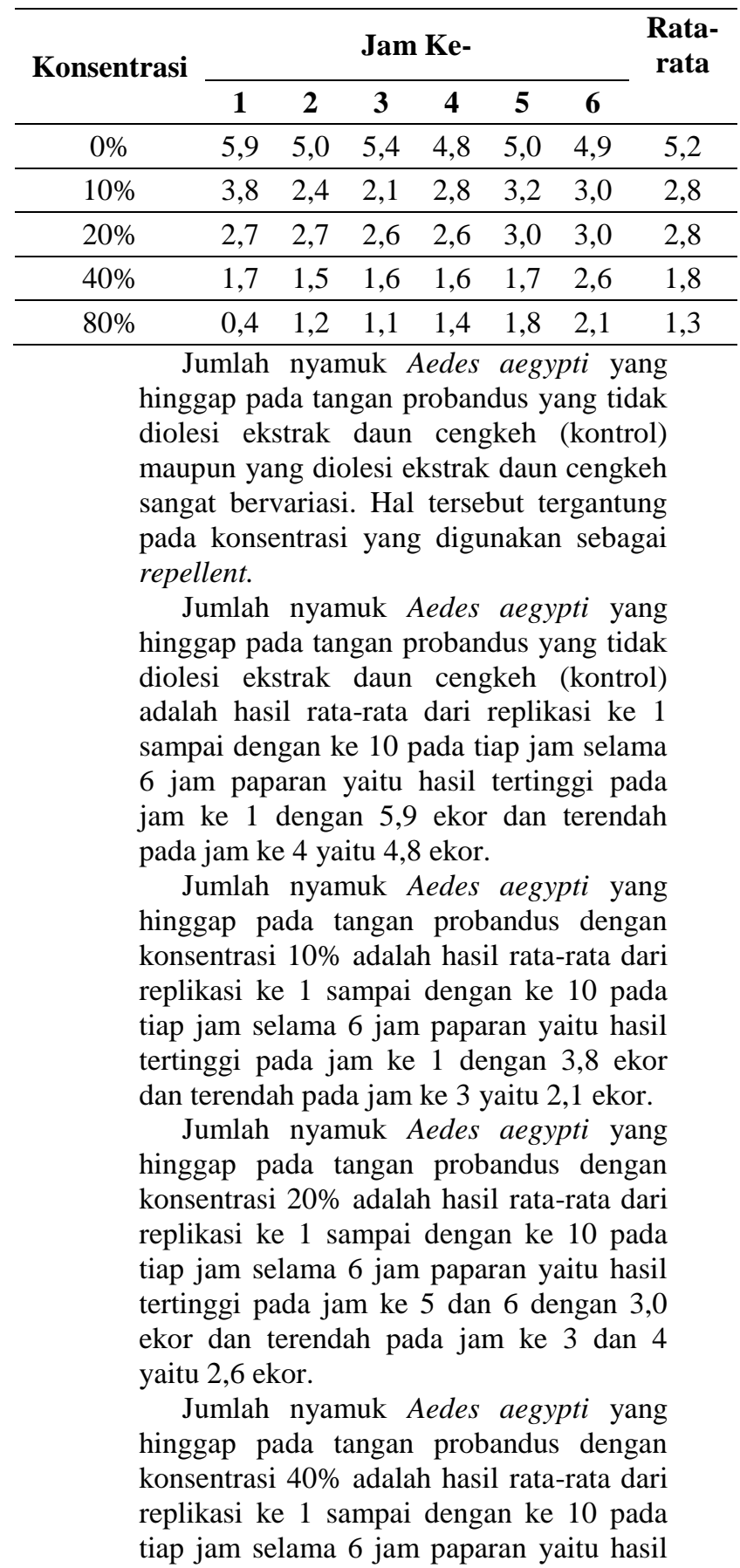

tertinggi pada jam ke 6 dengan 2,6 ekor dan terendah pada jam ke 2 yaitu 1,5 ekor.

Jumlah nyamuk Aedes aegypti yang hinggap pada tangan probandus dengan konsentrasi $80 \%$ adalah hasil rata-rata dari replikasi ke 1 sampai dengan ke 10 pada tiap jam selama 6 jam paparan yaitu hasil tertinggi pada jam ke 6 dengan 2,1 ekor dan terendah pada jam ke 1 yaitu 0,4 ekor.

Jumlah nyamuk Aedesaegypti yang hinggap pada tangan probandus sebagaimana ditunjukkan pada tabel 4.3 dapat diketahui bahwa tiap konsentrasi ekstrak daun cengkeh memiliki daya hinggap yang berbeda-beda, pada konsentrasi $0 \%$ (kontrol) rata-rata nyamuk yang hinggap antara 5,2 ekor pada 6 jam paparan, konsentrasi $10 \%$ antara 2,8 ekor nyamuk yang hinggap pada 6 jam paparan, konsentrasi $20 \%$ antara 2,8 ekor pada 6 jam paparan, konsentrasi $40 \%$ antara 1,8 ekor pada 6 jam paparan dan konsentrasi $80 \%$ antara 1,3 ekor nyamuk yang hinggap pada 6 jam paparan.

d. Daya hinggap nyamuk Aedes aegypti

Daya hinggap dapat dihitung dengan menggunakan data nyamuk Aedes aegypti yang hinggap pada tangan probandus dengan menggunakan rumus sebagai berikut :

Daya Hinggap $=\frac{\text { Banyak nyamuk hinggap }}{\text { Jumlah nyamuk uji }} \mathrm{X}$ $100 \%$

Daya hinggap nyamuk Aedes aegypti setelah dihitung menggunakan rumus tersebut adalah sebagai berikut :

Tabel 4.4 Daya Hinggap Nyamuk Aedes aegypti

\begin{tabular}{ccc}
\hline $\begin{array}{c}\text { Konsentrasi } \\
\text { Ekstrak } \\
\text { Daun } \\
\text { Cengkeh } \\
(\%)\end{array}$ & $\begin{array}{c}\text { Total } \\
\text { Rata-rata } \\
\text { Nyamuk } \\
\text { Hinggap }\end{array}$ & $\begin{array}{c}\text { Daya } \\
\text { Hinggap } \\
(\%)\end{array}$ \\
\hline $0 \%$ & 5,2 & 20,8 \\
\hline $10 \%$ & 2,8 & 11,2 \\
\hline $20 \%$ & 2,8 & 11,2 \\
\hline $40 \%$ & 1,8 & 7,2 \\
\hline $80 \%$ & 1,3 & 5,2
\end{tabular}

Daya hinggap nyamuk Aedes aegypti sebagaimana ditunjukkan pada tabel 4.4 dapat diketahui bahwa masing-masing konsentrasi mempunyai daya hinggap yang 
berbeda-beda yaitu konsentrasi $0 \%$ (kontrol) mempunyai daya hinggap $(20,8 \%)$, konsentrasi $10 \%$ mempunyai daya hinggap sebesar $(11,2 \%)$, konsentrasi $20 \%$ mempunyai daya hinggap sebesar $(11,2 \%)$, konsentrasi $40 \%$ mempunyai daya hinggap sebesar $(7,2 \%)$ dan konsentrasi $80 \%$ mempunyai daya hinggap sebesar $(5,2 \%)$.

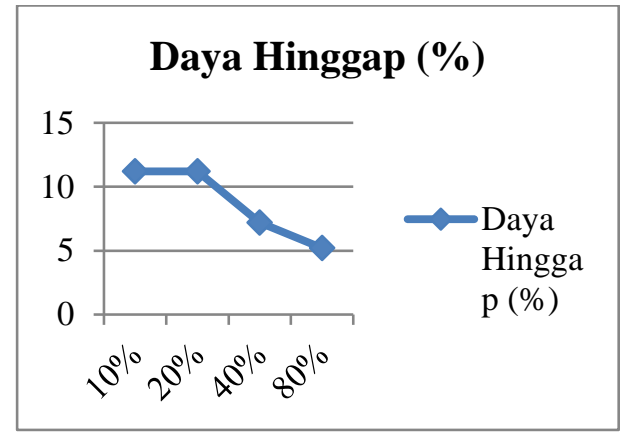

Daya hinggap nyamuk Aedes aegypti sebagaimana ditunjukkan pada gambar 4.1 dapat diketahui bahwa semakin tinggi konsentrasi maka daya hinggap nyamuk Aedes aegypti semakin berkurang. Hal tersebut dapat dipahami karena semakin tinggi konsentrasi maka kandungan senyawa metabolik sekunder juga semakin tinggi. Ekstrak daun cengkeh dikatakan efektif sebagai repellent apabila hinggapan nyamuk pada tangan probandus yang diolesi ekstrak daun cengkeh semakin kecil.

Daya hinggap yang dihasilkan karena adanya kandungan aktif sebagai insektisida pada daun cengkeh yaitu eugenol, saponin, flavonoid dan tanin. Eugenol dapat mempengaruhi susunan saraf yang khas dipunyai serangga dan tidak terdapat pada hewan berdarah panas, senyawa ini dapat menyebabkan kematian serangga (Nurdjannah, 2004). Saponin dapat menurunkan aktivitas enzim pencernaan dan penyerapan makanan, pengaruh saponin terlihat pada gangguan fisik serangga bagian luar (kutikula) yakni mencuci lapisan lilin yang melindungi tubuh serangga dan menyebabkan kematian karena kehilangan banyak cairan tubuh, saponin juga dapat masuk melalui organ pernapasan dan menyebabkan membran sel rusak atau proses metabolisme terganggu (Novizan, 2002). Flavonoid merupakan senyawa pertahanan tumbuhan yang dapat bersifat menghambat makan serangga dan juga bersifat toksik (Nurdjannah, 2004). Tanin berperan sebagai pertahanan tumbuhan dengan cara menghalangi serangga dalam mencerna makanan. Tanin dapat menurunkan kemampuan mencerna makanan dengan cara menurunkan aktivitas enzim pencernaan (protease dan amilase) serta mengganggu aktivitas protein usus. Serangga yang memakan tumbuhan dengan kandungan tanin tinggi akan memperoleh sedikit makanan, akibatnya akan terjadi penurunan pertumbuhan (Nurdjannah, 2004).

Penelitian sejenis yang pernah dilakukan adalah repellent dengan menggunakan ekstrak lengkuas (Awan Oktavia, 2014) yang menyebutkan konsentrasi $15 \%$ paling efektif sebagai repellent nyamuk Aedes aegypti karena rata-rata nyamuk yang hinggap 4 ekor dari 15 ekor nyamuk uji. Sejalan dengan hasil penelitian tersebut, hasil penelitian tentang repellent dari ekstrak daun cengkeh dengan konsentrasi $80 \%$ mempunyai daya hinggap $5,2 \%$ sehingga bisa dikatakan efektif sebagai repellent terhadap nyamuk Aedes aegypti.

\section{e. Hasil uji statistik}

Uji statistik digunakan untuk mengetahui jumlah nyamuk Aedes aegypti yang hinggap pada tangan probandus. Uji statistik yang digunakan yaitu dengan menggunakan One-Way Anova, selanjutnya untuk mengetahui perbedaan jumlah nyamuk yang hinggap antar konsentrasi digunakan uji LSD (Least Significant Difference).

\section{a) Uji Homogenitas}

Uji homogenitas digunakan dengan tujuan untuk mengetahui data yang ada bersifat homogen atau tidak. Data dikategorikan homogen jika mempunyai nilai $\mathrm{p}>0,05$.

Tabel 4.5 Uji Homogenitas

\begin{tabular}{lccr}
\hline \multicolumn{4}{c}{ Daya Hinggap Nyamuk } \\
\hline Levene Statistic & Df1 & Df2 & Sig. \\
\hline 1,185 & 4 & 25 & 0,342 \\
\hline Hasil uji & homogenitas & data \\
sebagaimana ditunjukkan pada tabel 4.5 \\
didapatkan hasil p=0,342 > & $0,05$. \\
Artinya data bersifat homogen & dan \\
dilanjutkan dengan uji Anova.
\end{tabular}




\section{b) Uji Anova}

Uji One-Way Anova digunakan dengan tujuan untuk mengetahui perbedaan jumlah nyamuk Aedes aegypti yang hinggap pada tangan probandus dengan berbagai konsentrasi.

Tabel 4.6 Uji Anova

\begin{tabular}{cccccc}
\hline \multicolumn{5}{c}{ Daya Hinggap Nyamuk } \\
\hline & $\begin{array}{c}\text { Sum of } \\
\text { Squares }\end{array}$ & Df & $\begin{array}{c}\text { Mean } \\
\text { Square }\end{array}$ & F & Sig. \\
\hline $\begin{array}{c}\text { Between } \\
\text { Groups }\end{array}$ & 52,758 & 4 & 13,190 & 60,875 & 0,000 \\
\hline $\begin{array}{c}\text { Within } \\
\text { Groups }\end{array}$ & 5,417 & 25 & 0,217 & & \\
\hline Total & 58,175 & 29 \\
\hline \multicolumn{5}{c}{ Hasil uji anova menunjukkan nilai } \\
p=0,000 < $\begin{array}{c}0,05, \text { artinya terdapat } \\
\text { perbedaan jumlah nyamuk yang } \\
\text { hinggap pada tangan probandus pada } \\
\text { tiap konsentrasi ekstrak daun cengkeh. }\end{array}$
\end{tabular}

\section{c) Uji LSD}

Uji LSD digunakan dengan tujuan untuk mengetahui jumlah nyamuk yang hinggap pada probandus antar konsentrasi. Hasil uji LSD selengkapnya terdapat pada tabel 4.7 sebagai berikut :

Tabel 4.7 Uji Least Significant Difference

Hasil uji LSD sebagaimana ditunjukkan pada tabel 4.7 dapat diketahui jika $\mathrm{p}<0,05$ maka ada perbedaan dan $\mathrm{p}>0,05$ tidak ada perbedaan. Konsentrasi $0 \%$ dengan $10 \% \mathrm{p}=0,000<0,05$ yang berarti ada perbedaan jumlah nyamuk yang hinggap pada tangan probandus. Konsentrasi 0\% dengan 20\% p=0,000 < 0,05 yang berarti ada perbedaan jumlah nyamuk yang hinggap pada tangan probandus. Konsentrasi $0 \%$ dengan $40 \% \mathrm{p}=0,000<0,05$ yang berarti ada perbedaan jumlah nyamuk yang hinggap pada tangan probandus. Konsentrasi 0\% dengan 80\% $\mathrm{p}=0,000<$ 0,05 yang berarti ada perbedaan jumlah nyamuk yang hinggap pada tangan probandus. Konsentrasi $10 \%$ dengan $20 \% \mathrm{p}=0,668>0,05$ yang berarti tidak ada perbedaan jumlah nyamuk yang hinggap pada tangan probandus. Konsentrasi $10 \%$ dengan $40 \% \mathrm{p}=0,000$ $<0,05$ yang berarti ada perbedaan jumlah nyamuk yang hinggap pada tangan probandus. Konsentrasi $10 \%$ dengan $80 \% \mathrm{p}=0,000<0,05$ yang berarti ada perbedaan jumlah nyamuk yang hinggap pada tangan probandus. Konsentrasi 20\% dengan $40 \% \mathrm{p}=0,001$ $<0,05$ yang berarti ada perbedaan jumlah nyamuk yang hinggap pada tangan probandus. Konsentrasi 20\% dengan $80 \% \mathrm{p}=0,000<0,05$ yang berarti ada perbedaan jumlah nyamuk yang hinggap pada tangan probandus. Konsentrasi $40 \%$ dengan $80 \% \mathrm{p}=0,107$ $>0,05$ yang berarti tidak ada perbedaan jumlah nyamuk yang hinggap pada tangan probandus.

Hasil analisis yang tidak ada perbedaan jumlah nyamuk yang hinggap pada tangan probandus adalah konsentrasi $10 \%$ dengan $20 \%$ dan konsentrasi $40 \%$ dengan $80 \%$. Konsentrasi yang efisien digunakan sebagai repellent nyamuk Aedes aegypti adalah konsentrasi $40 \%$ karena konsentrasi tersebut menghasilkan hasil statistik yang sama dengan konsentrasi $80 \%$.

\section{Kesimpulan}

a. Jumlah rata-rata nyamuk Aedes aegypti yang hinggap pada tangan kontrol yang telah diberi hand body lotion merek

\begin{tabular}{|c|c|c|c|}
\hline $\begin{array}{c}\text { Beda } \\
\text { Konsentrasi }\end{array}$ & $\begin{array}{c}\text { Mean } \\
\text { Difference }\end{array}$ & $\begin{array}{l}\text { Nilai p } \\
\text { (Sig.) }\end{array}$ & Keterangan \\
\hline $0 \%$ vs $10 \%$ & 2,2833 & 0,000 & Ada perbedaan \\
\hline $0 \%$ vs $20 \%$ & 2,4000 & 0,000 & Ada perbedaan \\
\hline $0 \%$ vs $40 \%$ & 3,3833 & 0,000 & Ada perbedaan \\
\hline $0 \%$ vs $80 \%$ & 3,8333 & 0,000 & Ada perbedaan \\
\hline $10 \%$ vs $20 \%$ & 0,1167 & 0,668 & Tidak ada perbedaan \\
\hline $10 \%$ vs $40 \%$ & 1,1000 & 0,000 & Ada perbedaan \\
\hline $10 \%$ vs $80 \%$ & 1,5500 & 0,000 & Ada perbedaan \\
\hline $20 \%$ vs $40 \%$ & 0,9833 & 0,001 & Ada perbedaan \\
\hline $20 \%$ vs $80 \%$ & 1,4333 & 0,000 & Ada perbedaan \\
\hline $40 \%$ vs $80 \%$ & 0,4500 & 0,107 & Tidak ada perbedaan \\
\hline $\begin{array}{rr}\text { b. } & \mathrm{J} \\
\mathrm{y} \\
\mathrm{s} \\
\mathrm{d} \\
\mathrm{e} \\
\mathrm{k}\end{array}$ & \multicolumn{3}{|c|}{$\begin{array}{l}\text { "X" adalah 5,2 ekor. } \\
\text { Jumlah rata-rata nyamuk Aedes aegypti } \\
\text { yang hinggap pada tangan probandus } \\
\text { setelah diolesi ekstrak daun cengkeh } \\
\text { dengan konsentrasi } 10 \% \text { adalah } 2,8 \\
\text { ekor, konsentrasi } 20 \% \text { adalah } 2,8 \text { ekor, } \\
\text { konsentrasi } 40 \% \text { adalah } 1,8 \text { ekor, }\end{array}$} \\
\hline
\end{tabular}


c. Hasil analisis daya hinggap pada masing-masing konsentrasi adalah konsentrasi $0 \%$ (kontrol) mempunyai daya hinggap (20,8\%), konsentrasi $10 \%$ mempunyai daya hinggap $(11,2 \%)$, konsentasi $20 \%$ mempunyai daya hinggap (11,2\%), konsentrasi $40 \%$ mempunyai daya hinggap $(7,2 \%)$, dan konsentrasi $80 \%$ mempunyai daya hinggap $(5,2 \%)$.

d. Hasil analisis uji anova menunjukkan nilai $\mathrm{p}=0,000<0,05$, artinya terdapat perbedaan jumlah nyamuk yang hinggap pada tangan probandus pada konsentrasi 0\% (kontrol), 10\%, 20\%, $40 \%$ dan $80 \%$.

e. Konsentrasi $80 \%$ merupakan konsentrasi yang paling efektif karena daya hinggap nyamuk sebesar 5,2\% dan rata-rata nyamuk yang hinggap 1,3 ekor dari 25 ekor nyamuk uji.

\section{Daftar Pustaka}

Boesri, Hasan, dkk. 2015. Uji Repelen (Daya Tolak) Beberapa Ekstrak Tumbuhan Terhadap Gigitan Nyamuk Aedes aegypti Vektor Demam Berdarah Dengue. Vektora Vol. 7 No. 2, Oktober 2015: 79-84, https://www.neliti.com/publications /127121/uji-repelen-daya-tolakbeberapa-ekstrak-tumbuhanterhadap-gigitan-nyamuk-aedes-a (25 April 2018)

Cahyono, Tri. 2014. Pedoman Penulisan Proposal Penelitian dan Karya Tulis Ilmiah/Skripsi Edisi Revisi Ketiga. Purwokerto : Kementerian Kesehatan RI Politeknik Kesehatan Jurusan Kesehatan Lingkungan Purwokerto.

Candra, Aryu. 2010. Demam Berdarah Dengue : Epidemiologi, Patogenesis, dan Faktor Risiko Penularan. Aspirator Vol. 2 No. 2 Tahun 2010: 110-119, http://ejournal.litbang.depkes.go.id/i ndex.php/aspirator/article/view/295 1 (25 Oktober 2017)

Departemen Kesehatan RI. 2004. Ekologi dan Aspek Perilaku Vektor. Jakarta : Ditjen PP \&PL.
Departemen Kesehatan RI. 2007. Ekologi dan Aspek Perilaku Vektor. Jakarta : Ditjen PP \& PL.

Farida, Ika. 2017. Formulasi Losion Minyak Astiri Daun Rosemary (Rosemarinus officinalis L.) Dengan Variasi Penambahan Konsentrasi Gliserin Sebagai Repellent Nyamuk Aedes aegypti. Semarang : Universitas Wahid Hasyim.

Hadipoentyanti, Endang. 1997. Tipe dan Karakteristik Cengkeh (Syzygium aromaticum (L.) Merr dan Perry). Balai Penelitian Tanaman Rempah dan Obat : Bogor.

Juliani, Nurlaeli. 2016. Efektivitas Ekstrak Daun Sirsak (Annona muricata, L) Sebagai Repellent Nyamuk Aedes aegypti Di Lokalitbang P2B2 Ciamis. Purwokerto : Politeknik Kesehatan Kemenkes Semarang.

Kardinan, A. 2003. Tanaman Pengusir dan Pembasmi Nyamuk. Jakarta : Agro Media Pustaka

Kementrian Kesehatan RI. 2012. Pedoman Penggunaan Insektisida (Pestisida). Jakarta: Ditjen PP \& PL.

Kementerian Kesehatan RI. 2013. Pedoman Pengendalian Demam Berdarah Dengue di Indonesia. Jakarta : Ditjen PP \& PL.

Manaf, Syalfinaf. 2009. Konservasi Hayati. Vol. 05 No. 02 Oktober 2009, hlm. 31-37, http://repository.unib.ac.id/7835/1/J urnal\%20Jarulis-Aristo-SantiOktober\%202013.pdf (25 Oktober 2017)

Manurung, Rofirma, dkk. 2013. Pengaruh Daya Tolak Perasan Serai Wangi (Cymbopogon nardus) Terhadap Gigitan Nyamuk Aedes aegypti. Volume 2 Nomor 1 2013, https://jurnal.usu.ac.id/index.php/lk k/article/view/997/602 (2 April 2018) 
Novizan. 2002. Membuat dan Memanfaatkan Pestisida Ramah Lingkungan. Jakarta : Agro Media Pustaka.

Nurdjannah, Nanan. 2004. Diversifikasi Penggunaan Cengkeh. Vol.3 No.2, Desember 2004:61-70, http://ejurnal.litbang.pertanian.go.id /index.php/psp/article/viewFile/558 4/4759 (25 Oktober 2017)

Puspita, Mega. 2009. Studi Efektivitas Berbagai Konsentrasi Ekstrak Serai Wangi (Cymbopogon nardus) Dalam Hand and Body Lotion Sebagai Repellent Nyamuk Aedes aegypti Di Banjarnegara. Purwokerto : Politeknik Kesehatan Kemenkes Semarang.

Prasetyowati, Heni, dkk. 2016. Seputar Dengue Dan Malaria. Bandung : CV Media Akselerasi.

Prasetyowati, Heni, dkk. 2016. Pestisida Nabati Dalam Pengendalian Demam Berdarah Dengue. Bandung : CV Media Akselerasi.

Rusdi. 2016. Implementasi Tanaman Potensi Insektisida Alami Sebagai Anti Nyamuk Demam Berdarah Dengue. Vol 4, No 1, Juli 2016, http://ojs.stikesmuda.ac.id/index.ph p/ilmu-kesehatan/article/view/25/7 (17 Desember 2017)

Soegijanto, Soegeng. 2008. Demam berdarah Dengue Edisi 2. Surabaya : Airlangga University Press.

Sudarmo, Subiyakto. 1991. Pestisida. Yogyakarta : Kanisius.

Sukana, Bambang. 1993. Pemberantasan Vektor DBD di Indonesia. Media Litbangkes Vol.III No.01, http://ejournal.litbang.depkes.go.id/i ndex.php/MPK/article/view/929 (22 Oktober 2017)

Talahatu, R Diana \& Papilaya. 2015. Pemanfaatan Ekstrak Daun Cengkeh (Syzygium aromaticumL.) Sebagai Herbisida Alami Terhadap
Pertumbuhan Gulma Rumput Teki (Cyperus RotundusL.). Biopendix, Volume 1, Nomor 2, Maret 2015, hlm. 149-159, https://ejournal.unpatti.ac.id/ppr_ite minfo_lnk.php?id=1124 November 2017)

Trijayanti, Suris. 2015. Pengaruh Pemakaian Perasan Daun Selasih (Ocimum basilicum) Sebagai Repellent Terhadap Jumlah Hinggap Nyamuk Aedes aegypti Tahun 2015. Purwokerto : Politeknik Kesehatan Kemenkes Semarang.

Yudhastuti, Ririh \& Anny Vidiyani. 2005. Hubungan Kondisi Lingkungan, Kontainer, dan Perilaku Masyarakat Dengan Keberadaan Jentik Nyamuk Aedes aegypti Di Daerah Demam Berdarah Dengue Surabaya. Jurnal Kesehatan Lingkungan, Vol.1, No.2, Januari 2005, http://www.journal.unair.ac.id/filerP DF/KESLING-1-2-08.pdf (2 April 2018)

Yunita, Lestari, dkk. 2014. Potensi Ekstrak Daun Cengkeh (Syzygium aromaticum L.) Dalam Bentuk Lotion Sebagai Zat Penolak Terhadap Nyamuk Aedes aegypti. http://jurnal.polinela.ac.id/index.ph p/PROSIDING/article/view/398/27 0 (17 April 2018) 